\title{
ІНТЕГРУВАННЯ НАУКИ Й НАВЧАЛЬНОГО ПРОЦЕСУ ЯК УМОВА ФОРМУВАННЯ ДИДАКТИЧНОӤ КОМПЕТЕНТНОСТІ МАЙБУТНІХ УЧИТЕЛІВ ФІЛОЛОГІЧНИХ СПЕЦІАЛЬНОСТЕЙ У ВИЩИХ ПЕДАГОГІЧНИХ НАВЧАЛЬНИХ ЗАКЛАДАХ
}

\begin{abstract}
Міменіна Т. М. Інтегрування науки й навчального прочесу як умова формування дидактичної компетентності майбутніх учителів філологічних спеціальностей у вищих педагогічних навчальних закладах.

У статті теоретично обтрунтовано умову ефективного формування дидактичної компетентності майбутніх учителів філологічних спеціальностей у вищих педагогічних навчальних закладах иляххм послідовного інтегрування науки й навчально-виховного процесу. Розкрито особливості організаиії науково-дослідницької роботи студентів на основі застосування методів наукового пізнання як методів оволодіння навчальним предметом в умовах навчального пошуку.

Ключові слова: навчально-виховний процес, науково-дослідницька діяльність, майбутні учителі філологічних спечіальностей, вищий педагогічний навчальний заклад.

Мишенина Т. М. Интегрирование науки и учебного процесса как условие формирования дидактической компетентности будущих учителей филологических спечиальностей в высших педагогических учебных заведениях.

В статье теоретически обосновано условие эффективного формирования дидактической компетентности будущих учителей филологических специальностей в высших педагогических заведениях путем последовательного интегрирования науки и учебного процесса. Раскрыты особенности организации научно-исследовательской работы студентов на основе использования методов научного познания как методов овладения учебным предметом в условиях учебного поиска.

Ключевые слова: учебно-познавательный процесс, научно-исследовательская деятельность, будущие учителя филологических специальностей, высшее педагогическое учебное заведение.

Mishenina T. Integration of science and learning process as a condition of the formation of future teachers didactic philological specialties in higher educational institutions.

The paper theoretically substantiates efficient formation of future teachers didactic philological specialties in higher educational institutions by successive integration of science and education process. The features of the organization of research work of students through the use of methods of scientific knowledge as methods of mastering academic subjects in the school search.

Key words: teaching and learning process, research and development activities, future teachers philological specialties, higher teacher education institution.
\end{abstract}

В умовах формування культури нового типу, коли посилюється соціально-політичне значення наук, створюються оптимальні умови для органічного поєднання наук, технологій і видів духовної діяльності, що розкриває нові перспективи у розбудові вітчизняної вищої педагогічної освіти. Накопичений вагомий досвід 3 організації науково-дослідницької діяльності студентів ВПНЗ як складника професійної підготовки уможливлює оптимальне формування методологічне підгрунтя для якісної гуманітарної підготовки майбутніх фахівців.

Грунтовний аналіз наукової літератури стосовно загальних процесів розвитку академічної освітньої галузі, змісту вітчизняної кадрової політики і підготовки науково-педагогічних кадрів (К. Галкин, Г. Доброва, О. Микитюк, 
В. Онопрієнко); теоретико-методологічних праць щодо філософського аспекту використання науки як форми культурної творчості в контексті гуманітаризації вищої освіти, теорії й методології наукових досліджень (Н. Амелін, Г. Дресвянська, О. Сгорова, М. Пепер); розкриття педагогічних аспектів організації науково-дослідницької роботи у ВНЗ, професійного спрямування навчально-дослідницької діяльності майбутніх учителів, активізації науководослідницької роботи студентів під час вивчення фахово орієнтованих курсів в умовах ВНЗ переконує в актуальності розкриття проблеми формування дидактичної компетентності майбутніх фахівців шляхом інтегрування науководослідницької й навчально-пізнавальної діяльності студентів.

Meта cmammi - обгрунтувати умову формування дидактичної компетентності майбутніх учителів філологічних спеціальностей шляхом інтегрування науки й навчального процесу у ВПНЗ.

Реалізація мети передбачає детальний аналіз таких понять, як «навчальна діяльність», «пізнавальна діяльність», «навчально-пізнавальна діяльність», «науково-дослідницька діяльність», звернемо увагу на ті зміни, які відбуваються у якісних змінах організації науково-дослідницькою діяльністю студентів в умовах навчально-виховного процесу у ВПНЗ.

Вивчення навчальної діяльності базується на працях В. Давидова [2], О. Леонтьєва [5], В. Ляудис [7], Н. Тализіної [12].

«Діяльність - динамічна система взаємодії суб'єкта зі світом» [8, с. 101; 11], у процесі якої відбувається виникнення і втілення в об'єкті психічного образу і реалізації опосередкованих ним стосунків у предметній дійсності.

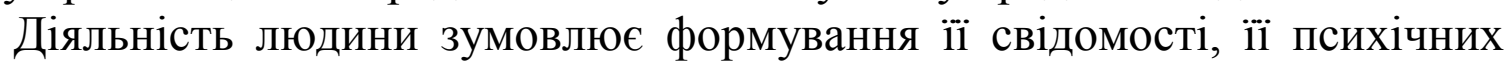
зв'язків, процесів і ознак, а останнє, здійснюючи регуляцію людської діяльності, $є$ умовою ії адекватного виконання. Для характеристики цього виду діяльності особи, що навчається, послуговуються поняттями «навчальна діяльність», «пізнавальна діяльність», «навчання».

Аналіз психолого-педагогічної літератури дозволяє дійти висновку, що ці поняття мають як спільні, так і відмінні риси. Деякі автори ототожнюють навчальну діяльність і навчання, пізнавальну і навчальну діяльність. Навчальну діяльність розглядають як більш широке поняття щодо пізнавальної діяльності, оскільки перше включає водночас і діяльність того, хто навчає і діяльність того, хто навчається. Навчально-пізнавальна діяльність розглядається як сумісна діяльність і форма співпраці викладача і студента, в якій здійснюються як пізнавальні процеси, так і соціалізація майбутнього фахівця.

Суттєво розширюють наше уявлення про зміст поняття «навчальна діяльність» розвідки відповідно до науково-педагогічних підходів: 1) діяльнісна теорія навчання, що розкриває поетапне формування розумових дій; навчання розуміється як спеціально організований вид діяльності людей, у процесі якого вони засвоюють досвід попередніх поколінь; 2) когнітивна теорія (навчання розуміється як вид інформаційного процесу; з іншого боку, процес навчання залишається в межах психології й описується за допомогою основних психічних функцій: сприймання, пам'яті, мислення); 3) психологічний підхід 
(навчання - чинник внутрішньої активності суб'єкта; навчання трактується як основна передумова розвитку).

У теорії навчальної діяльності концепція В. Давидова і Д. Ельконіна [2] переконливо доводять, що відмінність полягає в тому, що будь-яка людина отримує знання не тільки в процесі навчання, але і в праці, іграх та інших видах діяльності; при цьому здатність навчатися людина також розвиває в різних видах діяльності. Синтетичне поняття навчальнопізнавальної діяльності об'єднує пізнавальні функції (мислення, пам'ять, уявлення, увага та інше) з потребами, мотивами, емоціями людини.

Виходячи $з$ того, що навчально-пізнавальна діяльність, як і всі види діяльності, характеризується певною структурою (мотив, мета, умови, середовище), дослідники звернулися до аналізу її специфічних особливостей. У зв'язку з цим було виокремлено такі структурні компоненти, як постановка навчальної задачі, навчальні дії й операції із розв'язання задач, здійснення контролю за ходом й оцінкою результатів розв'язання задач.

Розгляд складової навчально-пізнавальної діяльності - навчальної діяльності - послідовно розкрив своєму дослідженні В. Давидов, який підкреслює необхідність виявляти і формулювати нові проблеми теорії навчальної діяльності з урахуванням того, що нові фактичні дані дозволяють уточнити ряд положень теорій навчальної діяльності; на основі цієї зміненої теорії - удосконалювати програми і методичні комплекси різних навчальних предметів [2]. Автор, розглядаючи проблеми теорії навчальної діяльності, наголошує на необхідності поглибленого аналізу асоціативного і діяльнісного підходів до навчання, з якими пов'язані пасивні й активні методи.

Узагальнюючи, робимо висновок про те, що навчально-пізнавальна діяльність має загальні риси, які утворюють іiі інваріантну структуру. Загальними рисами навчально-пізнавальної діяльності є: свідомий характер іiї суб'єкт ставить перед собою певну задачу і володіє здатністю до рефлексії власних дій; мета - мотиваційний аспект, перетворювальний характер навчально-пізнавальної діяльності; навчально-пізнавальна діяльність характеризується ознакою соціальності, пов'язана зі спілкуванням, взаємодією суб'єктів; є вираженням активності суб'єкта навчання.

Специфічними рисами навчально-пізнавальної діяльності задля ефективного управління нею $є: 1)$ спрямованість особи, що навчається, на оволодіння певними знаннями i навичками; 2) навчально-пізнавальна діяльність спрямована на засвоєння загальних способів дій (під способами дій у психології розуміють особливі системи, операції, завдяки яким людина відкриває ознаки предметів і явищ, які зумовлюють перетворення); 3) вивчення навчального матеріалу будується за принципом змістового узагальнення, коли засвоєння знань загального й абстрактного характеру передує ознайомленню з більш частими і конкретними знаннями - останні виводяться із перших як зі своєї єдиної основи [1]; 4) мета і результат полягає у змінах самого суб'єкта навчання (полягають в оволодінні певними способами дій, а не в зміні предметів, з якими діє суб'єкт) [13]. 
Зазначені особливості навчально-пізнавальної діяльності визначають іiі структуру: утворення складне, багаторівневе, іï аналіз охоплює різні рівні і допускає існування різних способів виокремлення іï змістового, операційного та мотиваційного компонентів, що дозволяє розкрити суттєві взаємозв'язки між знаннями, діями, мотивами, які можна звести до такого узагальнення: знання може бути засвоєним лише на основі відповідних дій, при цьому рівень узагальнення знання, його прогностичності і перенесення істотно залежить від того, на основі яких саме дій засвоювалося це знання.

Змістова сторона навчально-пізнавальної діяльності полягає не в тому, щоб з'ясувати, наскільки важливим є зміст знання, а у визначенні змісту, засвоєння якого необхідне для досягнення навчальних цілей, як головних, так і другорядних. Питання про вибір змісту засвоєних знань $є$ похідним від цілей навчання і виховання, які, у свою чергу, вимагають окремого розгляду. Оскільки будь-яка діяльність, а, відповідно, і навчально-пізнавальна, $\epsilon$ предметною, то можна стверджувати, що будь-який зміст стає предметом вивчення лише тоді, коли він становить для студента різновид певної задачі, що спрямовує і стимулює його діяльність. Зміст і структура матеріалу, що вивчається, повинні сприяти гармонійному поєднанню навчальнопізнавальної і професійної діяльності.

Організація дидактичного процесу відповідно до заданих цілей навчання і виховання передбачає розроблення конкретних методик побудови змістовної складової науково-дослідницької діяльності корелятивно до навчально-пізнавальної з урахуванням специфіки навчальних дисциплін, що вивчаються, і викладених вище вимог. Управління науково-дослідницькою діяльністю студентів мають їх забезпечити також системою вмінь і навичок теоретичної діяльності в рамках професії, що опановується, тому при проектуванні змістовної сторони навчально-пізнавальної діяльності на галузь засвоєння необхідно спрямовувати навчальну діяльність корелятивно до науки в цілому - знання і способи оперування ними, а також професійні задачі, які розв'язує спеціаліст у своїй діяльності.

Розглядаючи операційну складову навчально-пізнавальної й науководослідницької діяльності, установлено факт, що в сучасній психологопедагогічній літературі зміст знання розуміється в безпосередньому взаємозв'язку з ефективністю навчання в єдності зі способами дій із їх засвоєння $[1 ; 2]$. Розвивальний аспект навчання, роль знань у формуванні навчальної-пізнавальної й науково-дослідницької діяльності суттєво залежать від того, на основі яких саме дій ці знання сформовано.

Навчання як діяльність визнане рушійною силою розвитку особистості у працях Л. Виготського, Л. Занкова. Діяльнісні категорії навчання Л. Виготський позначав як «функції, які дозрівають»: «Навчання повинно орієнтуватися на вже пройдені цикли розвитку, на нижчий поріг навчання, однак воно спирається не стільки на дозрілі, скільки на функції, які дозрівають» $[1$, с.250]. Услід за Л. ВиготськимЛ. Занков переконливо довів, що діяльність навчання зумовлює розвиток особистості, а отже, розвиток суб'єктності 
навчання $є$ метою навчально-пізнавальної діяльності. Принципами такого навчання науковець уважав: провідну роль теоретичного знання, високий рівень труднощів у навчанні, швидкий темп засвоєння, усвідомлення суб’єктами навчання дидактичного процесу, цілеспрямований загальний розвиток особистості [3, с.323].

Аналіз поглядів науковців на процес навчання - розвитку особистості і ролі діяльності особистості в цьому процесі дозволив виокремити основні положення стратегії управління навчально-пізнавальною діяльністю у іi тісному взаємозв'язку 3 науково-дослідницькою діяльністю студентів ВПНЗ:навчання (пізнання) і розвиток особистості перебувають у єдності, причому навчання стимулює розвиток;навчання (пізнання) для особистості $€$ спонуканням до дій, які вдосконалюють процеси навчального дискурсу;студент має випробувати ті дії та операції, за допомогою яких знання складаються в систему ідей та понять; провідна роль навчання (пізнання) в розвитку особистості полягає у змісті засвоєних знань, похідними від яких є методи навчання (пізнання), форми його організації.

Отже, діяльність навчання фахово орієнтованих навчальних дисциплін (зокрема у вищому педагогічному навчальному закладі) розуміється як кероване й усвідомлене (з позиції суб'єктів - викладача та студента) оволодіння змістом навчання, який обіймає фахові знання, уміння (дії), навички (операції), а також оволодіння методами навчання. Цілісна координована схема навчання уможливлює розкриття i вияв основного відношення між: навчальним предметом і предметом навчання; навчальною співдіяльністю: усвідомленим учінням та дидактичним керуванням; суб'єктами, які здійснюють цю співдіяльність: викладачем та студентом.

Узагальнення дозволяють визначити управління навчальнопізнавальною й науково-дослідницькою діяльністю студентів є організацією співвідношення між усвідомленою навчально-пізнавальною й науководослідницькою діяльністю, системою теоретичних знань та системою нормативних умінь і навичок.

Дидактична стратегія управління навчально-пізнавальною й науководослідницькою діяльністю студентів становить проект навчального процесу 3 розподіленою співдіяльністю суб'єктів, який здійснюється за умов керованого усвідомленого оволодіння фахово орієнтованих навчальних дисциплін для задоволення фахових потреб і запитів студента, реалізації навчального діалогу.

Розглянемо аспектуально особливості організації науково-дослідницької діяльності студентів - майбутніх учителів філологічних спеціальностей сучасного ВПНЗ. Мотиви наукової (науково-дослідницької) діяльності студентів, як правило, пов'язані з прагненням зробити свій внесок у розв'язання загальносоціальних та загальнонаціональних проблем. Окрім того, вони є спорідненими з пізнавальною й особистісною мотивацією. Така спорідненість випливає 3 переліку внутрішніх спонук, які змушують студента займатися науковою роботою. До них відносять: прагнення до пізнання i створення чогось нового; бажання зрозуміти якесь явище 
самостійно і відтворити його специфіку на загал;інтерес до конкретного питання в науці;бажання принести користь своїм відкриттям людству; самореалізація та здійснення творчого пошуку; самоствердження у зв'язку із престижністю наукової роботи в суспільстві [4, с.281].

Системно-діяльнісний підхід в організації науково-дослідницької діяльності у ii тісному взаємозв'язку з навчально-пізнавальною забезпечує співдіяльність викладача і студента шляхом оптимального добору методів i прийомів 3 урахуванням можливостей активізації мислення студентів, спонукання їх до самостійних дій, спілкування, висновків, формування здатності до оброблення, систематизації, засвоєння навчальної інформації. За такої організації під час навчання фахово орієнтованої навчальної дисципліни задається експозиція - якісно специфічна система понять його констувальних, що дозволяє вибудовувати траєкторію пізнавального руху предметом шляхом переорієнтації цілей навчання в напрямку посилення методологічного компонента, націлюючи на розроблення методичних прийомів із формування методологічних умінь і використання їх в інструментальній функції.

Ефективність управління науково-дослідницькою діяльністю студентів також забезпечується послідовним використанням проблемного методу навчання, активізуючи розумову діяльність студентів шляхом розв'язання пошукових завдань, оскільки створена проблемна ситуація спонукає до пошуку переконливих рішень, розвиває потребу самовираження, самоактуалізації через навчальний діалог. В умовах проблемного навчання діяльність викладача складається 3 етапів навчального процесу, коли студентові надається інформація і створюються проблемні ситуації, організовується творчопізнавальна діяльність. На підставі аналізу фактів студенти самостійно роблять висновки, узагальнення, застосовують вже відомі знання в нових ситуаціях.

Кореляція навчально-пізнавальної діяльності й науково-дослідницької діяльності студентів в умовах сучасної інформаційної парадигми ВПНЗ виявляється у формуванні у майбутніх фахівців основ систематичних навичок здійснення наукових спостережень, виконання теоретичних й експериментальних самостійних науково-дослідних завдань; вироблення вмінь використовувати теоретичні знання для розв’язання практичних завдань; формування потреби в безперервній фаховій самоосвіті [9; 10].

Активне формування інтересу до сучасних методів досліджень у процесі здійснюваної науково-дослідницької діяльності майбутніх фахівців дозволяє максимально враховувати системно-діяльнісний підхід до навчального процесу в умовах ВПНЗ.

Орієнтувальними тактиками застосування методів є: абстракції (формування образів шляхом віднесення й доповнення, що виявляється в ускладнення, доповненні образу дійсності); узагальнення надає можливість охопити класи задач певного типу); аналогї (ефективний під час опису об'єктів пізнання під час засвоєння природничо-наукових знань, з'ясування співвідношення характеристик різнорідних об'єктів; можу бути ефективною за умов прогнозування, висунення навчальних гіпотез); класифікаціï 
(ефективний як спосіб уявлення змісту предметних знань в гуманітарних науках шляхом упорядкування, систематизації матеріалу на певній спільній основі; режим використання: висунення методу у якості стратегії розв'язання задачі; визначення основ для класифікації; віднайдення найбільш виразної i зручної форми подання досліджуваного змісту; значення методу важко переоцінити під час роботи зі значною кількістю узагальнюваних об'єктів); моделювання (забезпечує образну опору при узагальнювальному орієнтуванні у виучуваній предметній області; конституюються на відтворенні відношень і властивостей модельованого об'єкта за допомогою певних законів (формул); зображення становить ідеалізовану картину явища, заданого сюжетом задачі); індукиії /дедукиії перший різновид є одним із різновидів узагальнення, функція якого пов'язана із прогнозуванням результатів спостереження й експерименту; індуктивні узагальнення розглядаються почасти як дослідні істини та емпірійні закони; другий різновид передбачає перехід від загального до конкретного, систему міркувань, у яких, відштовхуючись від деяких тверджень (істин), можна дійти певного умовиводу; ефективним є при розв'язанні різносюжетних задач вивченню підлягає логічний ланцюжок дедуктивних умовиводів - обгрунтованість висновків і злагодженість логічних операцій з правилами й законами конкретно-предметної області) - становлять дієвий інструмент управління навчально-пізнавальною діяльністю студентів шляхом аналізу й розв'язання навчальних задач, уможливлюють досягнення високого рівня результативності науково-дослідницької роботи студентів.

Науково-дослідницька діяльність в умовах ВПНЗ забезпечує: а) єдність цілей і напрямків навчально-пізнавальної, наукової і виховної аспектів роботи; б) реалізацію взаємозв'язку і наступності форм і методів фахової підготовки студентів; в) безперевність науково-дослідницької діяльності, узгодження іiї 3 проблематикою ВНЗ; г) поглиблення фахово орієнтованих знань студентів і їх послідовне використання у процесі взаємонавчання; г) розвиток здатності визначати і формувати актуальну тематику наукових повідомлень і доповідей за результатами виконаних досліджень; д) формування науково-методологічного світогляду на основі цілісності всього навчально-виховного процесу.

Вимоги, що висуваються до змісту науково-дослідницької роботи студентів, детерміновані фахово орієнтованим спрямуванням усіх видів навчально-пізнавальної діяльності 3 напряму підготовки - філологія: 1) структурування теоретичного матеріалу має забезпечувати досягнення мети фахової підготовки, зміст якої послідовно обгрунтовано у кваліфікаційних характеристиках, сприяти усвідомленню прикладного значення навчальної дисципліни для майбутнього фаху; 2) змістовне наповнення досліджуваного матеріалу має бути методологічним, що $\epsilon$ засобом вироблення узагальнених умінь і навичок; 3) теоретична частина фахово орієнтованої навчальної дисципліни має містити фундаментальне ядро знань, що сприятиме формуванню у студентів наукової картини світу i сучасної методології іiі пізнання; 4) розроблення завдань самостійної науково-дослідницької роботи студентів варто формулювати в контексті 
майбутнього фаху, що сприятиме розумінню й усвідомленню логічної моделі об'єкта дослідження.

Окреслені вимоги до науково-дослідницької роботи уможливлюють:

1) урахування варіативних досліджень, які виходять за межі дидактично обробленої наукової галузі;

2) використання науково-дослідницької діяльності майбутніх фахівців як системоутворювальної соціокультурної детермінанти становлення особистості студента - майбутнього фахівця високого рівня.

Важливим аспектом науково-дослідницької діяльності майбутніх фахівців в умовах ВПНЗ є формування творчої особистості в умовах посилення ролі фундаментальної загальнонаукової підготовки студентів - компетентних спеціалістів. Можна цілком стверджувати, що науково-дослідницька діяльність майбутніх фахівців виявляє інтегративну якість майбутнього фахівця, що конституюється на основі творчих можливостей, умінні застосовувати технологію наукового дослідження. Інтелектуально-творчі якості особистості (дивергентність, оригінальність, асоціативність, інтелектуальна активність) набувають статусу інтеріоризованих у структурі особистісного утворення.

Науково-дослідницька діяльність студентів в умовах ВПНЗ дозволяє визначити зміст складника дидактичної компетентності в опануванні конкретної наукової галузі: уміння застосовувати адекватний методологічний апарат дослідження; уміння аналізувати інформаційні джерела щодо досліджуваного питання; уміння застосовувати технологію наукового дослідження (створення системно-діяльнісного підходу до організації наукового дослідження). Продовжуючи думку, визначаємо перспективність тенденції переструктурування змісту навчальних курсів, розробивши відповідно до освітньо-професійного напряму фундаментальні і спеціальні завдання науково-дослідницької діяльності; передбачити збільшення частки профільних завдань із виразно прикладним характером науково-дослідницької діяльності, пов’язаної зі специфікою майбутньої професійної діяльності; вивчення методологічних особливостей, визначальних у формуванні наукового мислення майбутнього фахівця.

Чотири компоненти змісту освіти - знання, уміння розв’язувати традиційні завдання, досвід творчої діяльності, досвід емоційно-оцінної діяльності - в межах трансформаційних змін в організації науково-дослідницької діяльності студентів ВПНЗ визначають іншу парадигму культуротворчості. Зокрема, рівнями реалізації наукового модулю визначено: загальнонауковий рівень (відтворює філософсько-світоглядні підходи до діяльності особи в соціокультурному середовищі як результату іiі культуро творчості); спеціально-науковий рівень (передбачає висвітлення проблеми зняття суперечливостей між соціальною потребою в перетворювальній активності особи та можливостями реалізації іï творчого потенціалу); фахово орієнтований рівень (формування цілісної картини створення нового у подальшій професійний діяльності). У такий спосіб система знань у студентів формується як певний комплекс провідних ідей, концепцій, парадигм, загальних 
теоретичних понять, перспективних методик культуротворчості, що сприяє досягненню високого рівня дидактичної компетентності майбутніх фахівців.

Отже, стратегія управління навчально-пізнавальною діяльністю студентів філологічних спеціальностей в умовах ВРНЗ у іiі тісному взаємозв'язку 3 науково-дослідницькою оптимально поєднує системнодіяльнісний і проблемний підходи до навчання; усуває суперечність сучасної вищої школи між традиційними цілями загальної і професійної освіти, змінюе канонізовані лекційно-семінарські форми організації навчальної діяльності майбутніх фахівців; дозволяє розмежувати поняття змісту навчання як дидактично обробленої інформації і змісту освіти як рівня розвитку особистості майбутнього фахівця, іiі предметної і соціальної складових як результату реалізації проекту взаємозв'язаної діяльності викладача і студентів по розгортанню змісту навчання.

\section{Література}

1.Выготский Л. С. Избранные психологические исследования: Мышление и речь / Лев Семенович Выготский. - М. : Изд-во АПН РСФСР, 1956. - 518 с.

2.Давыдов В. В. Проблемы развивающего обучения / Василий Васильевич Давыдов. - М. : Педагогика, 1981. -423 с.

3.Занков Л. В. Избранные педагогические труды. - М. : Новая школа, 1996. - 432 с.

4. Ильин Е. Мотивация и мотивы / Евгений Павлович Ильин. - СПб. : Питер, 2003. -512 с.

5.Леонтьев А. Н. Деятельность. Сознание. Личность / Алексей Николаевич Леонтьев. - М. : Смысл ; Изд. центр «Академия», 2004. - 352 с.

6.Лернер И. Я. Проблема методов обучения и пути ее исследования / Исаак Яковлевич Лернер // Вопросы методов педагогических исследований. - М. : НИИ Общей педагогики АПН СССР, 1973. - С. 21-34.

7.Ляудис В. Я. Формирование учебной деятельности студентов / под ред. В. Я. Ляудис. - М. : Изд-во МГУ, 1989. - 240 с.

8.Махмутов М. И. Проблемное обучение: основные вопросы теории : [учеб. пособ.] / Мирза Исмаилович Махмутов. - М. : Педагогика, 1975. - 368 с.

9.Микитюк О. М. Становлення та розвиток науково-дослідної роботи у вищих педагогічних закладах України (історико-педагогічний аспект) / О.М.Микитюк. Харків : ОВC, 2001. - 256 c.

10. Науково-практичні аспекти аспекти організації навчальної і методичної роботи в університеті : [монографія]. - Донецьк : Юго-Восток, 2004. - 254 с.

11. Словник іншомовних слів: 23000 слів та термінологічних словосполучень / уклад. Л. О. Пустовіт та ін. - К. : Довіра, 2000. - 1081 с.

12. Талызина Н. Ф. Управление процессом усвоения знаний / Нина Федоровна Талызина. - М. : Изд-во Моск. ун-та, 1975. - 342 с.

13. Rubin J. Study of Cognitive Processes in Second Language Learning / J. Rubin // Applied Linguistics. - 1981. - Vol. 11. - Pp. 117-131.

Стаття надійшла до редакції 23.05.2012 p. 